\title{
EFFECTS OF ORAL CLEAR KEFIR PROBIOTICS ON GLYCEMIC STATUS, LIPID PEROXIDATION, ANTIOXIDATIVE PROPERTIES OF STREPTOZOTOCIN INDUCED HYPERGLYCEMIA WISTAR RATS
}

\author{
Judiono1; Djokomoeljanto2; dan Hadisaputro.S² \\ 1 Lecurer in The Bandung Health Polytechnic, Ministry of Health Republic Indonesia \\ ${ }^{2}$ Professor in Medicine, Medical Faculty, Diponegoro University, Semarang
}

\section{ABSTRACT}

Hyperglycemia causes excessive free radicals, may increase reactive oxygen species, lipid peroxidation, and reduced antioxidants as well as dysfuntion of the pancreatic $\beta$ cells. This study was aiming to investigate the effect of oral Clear kefir probiotic on glycemic status, lipid peroxidation and antioxidantive properties of Streptozotocin induced hyperglycemia Wistar Rats. The randomized pretest - posttest control group study design was conducted in 84 male hyperglycemia Wistar rats induced by $40 \mathrm{mg} / \mathrm{kg}$ bw streptozotocin (STZ) dissolved in 0,1 M buffer citrate pH 4,5. Rats were randomized into four groups, namely: (1) STZ-induced animals group and given insulin treatment UI/200 $0.76 \mathrm{~g} \mathrm{bw}$, (2) STZ-induced animals group and given treatment clear kefir $3.6 \mathrm{cc} / 200 \mathrm{~g}$ bw/day for 30 days, (3) STZ-induced animals group as a positive control (ad libitum), (4) normal animals group as a negative control (ad libitum). Blood glucose was measured by enzymatic method. Lipid peroxidation measured of MDA-TBARs by spectrophotometry. SOD and GPX Antioxidants were measured by ELISA. Catalase was measured by spectrophotometry. Probiotics Clear kefir characterization was done by microbiology identification. Data were analyzed by One Way Anova, Kruskall Walis, Duncan, Mann Whitney test with significance level $p$ $<0.05$. The result showed that clear kefir supplementation $3.6 \mathrm{cc} /$ day for 30 days administration, affected on blood glucose, MDA and increased antioxidant capacity. Statistical analysis showed that there were respectively decreased of glucose $(p<0.001)$, MDA ( $p<0.001)$. SOD antioxidant capacity was increased $(<0,05)$, in addition GPx and Cat were also inceased $(p<0,001)$, except in control groups. Probiotics kefir was found as many as $10^{6}-10^{9} \mathrm{cfu} / \mathrm{mL}$ and declined to $10^{5}$ as the decrease in $\mathrm{pH}$ during storage, four species of probiotics were detected, such as: Lactobacillus Sp, Sp Lactococcus and Acetobacter and Saccharomyces $\mathrm{Sp}$. In conclusion, kefir supplementation significantly decreased the blood glucose level, level of MDA and increased of antioxidants capacity. The number of probiotics declined during storage. It is interesting to identify a potential clear kefir probiotics in a pathogenesis of the $\beta$ cells pancreatic repair and stability product during storage for future study.

Keywords: probiotic, hyperglycemia, free radicals, lipid peroxidation, antioxidant

\section{ABSTRAK}

\section{EFEK PROBIOTIK KEFIR BENING TERHADAP STATUS GLIKEMIK, PEROKSIDASI LIPID, STATUS ANTIOKSIDAN TIKUS WISTAR HIPERGLIKEMIA DIINDUKSI STREPTOZOTOCIN (STZ)}

Hiperglikemia menyebabkan peningkatan radikal bebas dan spesies oksigen reaktif, peroksidasi lipid, penurunan antioksidan serta disfungsi sel $\beta$ pankreas. Penelitian ini bertujuan untuk memvalidasi efek probiotik kefir bening terhadap status glikemik, peroksidasi lipid dan status antioksidan pada Tikus Wistar hiperglikemia diinduksi (STZ). 'Pretest - posttest control group study design' dilakukan pada 84 tikus Wistar jantan hiperglikemia yang diinduksi $40 \mathrm{mg} / \mathrm{kg} \mathrm{bb} \mathrm{STZ} \mathrm{dilarutkan} \mathrm{pada} \mathrm{buffer} \mathrm{sitrat} \mathrm{pH} \mathrm{0,1} \mathrm{M} \mathrm{4,5.} \mathrm{Tikus}$ secara acak dikelompokkan empat kelompok, yaitu: (1) kelompok hewan di STZ dan diberikan pengobatan insulin UI/200 0,76 g bb, (2) kelompok hewan di STZ dan diberikan diberikan kefir bening 3,6 cc /200 bb/ 30 hari, (3) kelompok hewan di STZ sebagai kontrol positif, (4) kelompok hewan kontrol negatif. Glukosa darah diukur dengan metode enzimatik. Peroksidasi lipid diukur MDA-TBARS dengan spektrofotometri. Antioksidan SOD dan GPX diukur dengan ELISA. Katalase diukur dengan spektrofotometri. Karakterisasi probiotik kefir bening dilakukan dengan identifikasi mikrobiologi. Data dianalisis dengan One Way Anova, Kruskall Wallis, Duncan, Mann Whitney test dengan tingkat signifikansi $p<0,05$. Hasil penelitian menunjukkan suplementasi oral kefir bening 3,6 cc/hari selama 30 hari berpengaruh terhadap glukosa darah, MDA dan meningkatnya status antioksidan. Analisis statistik menunjukkan penurunan glukosa $(p<0,001)$, MDA $(p<0,001)$. Status antioksidan SOD meningkat $(p<0,05)$, di samping GPX dan Cat juga meningkat $(p<0.001)$, kecuali kontrol. Probiotik kefir bening ditemukan sebanyak $10^{6}-10^{9} \mathrm{cfu} / \mathrm{mL}$ dan 
menurun sejalan penurunan $\mathrm{pH}$ selama penyimpanan. Probiotik yang terdeteksi, seperti: Lactobacillus Sp, Acetobacter Sp Lactococcus dan Saccharomyces Sp. Dari penelitian ini disimpulkan bahwa suplementasi kefir bening secara signifikan menurunkan glukosa darah, MDA dan meningkatkan kapasitas antioksidan. Jumlah probiotik menurun selama penyimpanan. Identifikasi probiotik kefir bening berpotensi perbaikan sel-sel $\beta$ pankreas dan stabilitas produk selama penyimpanan sangat menantang penelitian masa depan.

\section{Keywords: probiotik, hiperglikemia, radikal bebas, peroksidasi lipid, antioksidan}

\section{INTRODUCTION}

$\mathrm{D}$ iabetes mellitus (DM) is becoming a serious metabolic disease pandemic. ${ }^{1}$ Type 2 of diabetes mellitus is an insulin defective mobilization of blood glucose into the tissues and body metabolism. This disease is characterized by syndrome of hyperglicemia. Acute hyperglycemia increases free fatty acids, insulin resistance, besides reduces of the organ of Langerhans and pancreatic $\beta$ cell volume by $60 \%{ }^{2}$ It also initiates serious diabetes complications. Consequently, it will affect the quality of human resources and nation development in the long term. ${ }^{3}$

Hyperglycemia increases free radicals and oxidative stress. Free-radicals are raised via several mechanisms, such as: (1) nonenzymatic glycation (AGEs), (2) glucose autooxidation, (3) polyol pathway and protein kinase (PKC).4-9 Excessive free radicals affect the imbalance of ROS production and the body cellular defenses, so the tissues are suspected vulnerable due to oxidative stress. ${ }^{10}$ Oxidative stress affects organ cells damage, enzymes, up to lower an immune response level, and produces increased lipid peroxidation and as well as pancreatic $\beta$ cell dysfunction.

Lipid peroxidation increases hydroxyl free radicals $\left({ }^{*} \mathrm{OH}\right)$ which then attacks the membranes of endothelial cells. The reaction leads to brake chain fatty acids continuously. Polyunsaturated fatty acid is converted into other compounds such malondialdehyde (MDA). ${ }^{11-13}$ Findings showed that MDA and ROS levels were higher in diabetic than non diabetic. ${ }^{14}$.

Increasing reactive oxigen species (ROS) in mitochondria will damage deoxyribonucleic acid (DNA), produces inflammation pathogenesis and pancreatic $\beta$ cell dysfunction. ${ }^{15}$ The pancreatic $\beta$ cells are susceptible to oxidative stress, as a result, antioxidants are needed for neutralization. Moreover, the body has the ability to ward off free radicals by activating the body's antioxidant system and supplemented from food sources. ${ }^{16-}$ 17

Diabetes therapy has been demonstrated to the mechanism where the body is unable in achieving maximal glucose with helping of the availability of current therapy approaches. ${ }^{18}$ The use of insulin and medication are the most effective options, but it is difficult to implement as they relate to socioeconomic conditions, knowledge and understanding of residual effect after taking medicine. Recently, people are growing to be aware of using Clear kefir's probiotics supplementation as reported elsewhere, but the results have been conflicting in relation to the application of therapy. Further studies are therefore important to ensure the consistency of the results. ${ }^{19}$

Clear kefir probiotics produced a bioactive substances that has the ability as an immunomodulator and antioxidants capacity $20-23$ and hypocholesterolemic. The underlying mechanism is probably occurred via its bioactive components; for example exopolyssacharide, peptide, antioxidant and through immunomodulatory properties. ${ }^{14-17}$ Exopolysaccharides reduce blood glucose and enter the biometabolism, which will affect the reduction of free radicals and inhibit glucotoxicity. Similarly, kefir antioxidants are neutralized by peroxides molecules and activated the body's antioxidant system. Hypocholesterolemic effects will be attached and neutralized to be endogenous cholesterol by binding with salt bile hydrolyzed enzyme. Cholesterol reduction enables inhibiting free fatty acids level as well as lipid peroxidation. Reduction of lipid peroxidation and free fatty acids can prevent lipotoxicity.

Aims of the investigation were to validate the effect of Clear kefir on glycemic status, lipid peroxidation, antioxidative properties of streptozotocin induced hyperglycemia Wistar rats. The authenticity of this research is in the choice of research methods for studying biomedical variables that may clear the 
mechanism of the effect of a biomolecular Clear kefir. The preferred indicators include lipid peroxidation (MDA) and antioxidants status (SOD, GPX and Catalase), This study used animal model due to the ease of handling, and intended to explore deeply to the mechanism of Kefir action, before applying it to the human system.

\section{MATERIALS AND MENTHODS}

This research was randomized control group pretest-posttest design ${ }^{24}$ on subjects of 60 male hyperglycemia rats aged 2.5 to 3 months, body weight (bw) around 150-250 g. Wistar rats were injected intra peritoneally by 40 $\mathrm{mg} / \mathrm{kg}$ bw streptozotocin (STZ) dissolved in 0,1

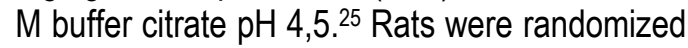
into four groups, namely: (1) STZ-induced group and given insulin treatment $0.76 \mathrm{UI} / 200 \mathrm{mg} \mathrm{bw}$, (2) STZ-induced group and given treatment Clear kefir $3.6 \mathrm{cc} / 200 \mathrm{~g}$ bw/day for 30 days, (3) STZ-induced group as a positive control (ad libitum), (4) normal group (Non STZ-induced) as a negative control (ad libitum).

Blood serum collection. Animals were anesthetized with a ketamin $0.1 \mathrm{ml}$, dissolved in $1 \mathrm{ml}$ steril aquadest and injected to every animals with $1 \mathrm{ml}$. Wait a few moments until the animals experienced a decrease in consciousness, then was taken retro-orbitally venous blood through the capillary pipette.

Kefir was made from the 24 hours fermented skim milk by kefir grains commercial inoculum obtained from the House of Kefir Bening Semarang. Animals were feed by AIN 93 standard diet. ${ }^{26}$

Blood glucose was measured with a Super Glucocard II using enzymatic methods. Lipid peroxidation was measured of Thiobarbituric
Acid Subtances (TBARs) by spectrophotometry. Antioxidant status (Cat) was measured by spectrophotometry. Antioxidant status (SOD, GPX) were measured by ELISA. Statistical analysis presented in univariate data (mean, $\mathrm{SD}$ ) and bivariate (Kruskal Wallis, ANOVA / Post Hoc Duncan's Multiple Range Test with significance level of 0.05 . Rats were obtained from the Integrated Research and Development Institute of Unit IV (LPPT) University of Gajah Mada Yogyakarta. This research was approved by Research Ethics Committee for Health Research, Medicine Faculty, Diponegoro University, Semarang and Dr. Kariadi General Hospital, Semarang.

\section{RESULTS}

Table 1 showed a weight increase of animals among groups, except in control positive group. They gained with very small achievement bout 4,01 $\pm 16,82 \mathrm{~g}$. Other groups were gained more than $13.80 \pm 16.10 \mathrm{~g}$. Statistical analysis found no difference among groups of animals ( $p>0.05)$. The delta of blood glucose showed a reduction in the insulin group about $-162,29 \pm 76,75 \mathrm{mg} / \mathrm{dL}$ and Clear kefir group about $-111,00 \pm 44.23 \mathrm{mg} / \mathrm{dL}$, in the contrary, in the control group showed an increase. Both insulin and kefir pontentially reduced blood glucose, but insulin was the best agent.

Findings showed that Clear kefir reduced blood glucose significantly $(p<0.001)$ as well as lipid peroxide (MDA) levels $(p<0.001)$, except in control group. Thus, this study has been proved the hypothesis and build a whole new theory (novel) correctly that suplementation Clear kefir reduced blood glucose and MDA level significantly.

Table 1

The change of some values from various variables among experimental animals groups

\begin{tabular}{|c|c|c|c|c|c|}
\hline \multirow[b]{2}{*}{ Variables } & \multicolumn{4}{|c|}{ Delta Experimental Animal Groups } & \multirow[b]{2}{*}{$p$} \\
\hline & $\begin{array}{l}\text { Insulin } \\
\chi \pm S D \\
\end{array}$ & $\begin{array}{c}\text { Clear Kefir } \\
\chi \pm S D\end{array}$ & $\begin{array}{c}\text { Positive Control } \\
\chi \pm \text { SD }\end{array}$ & $\begin{array}{c}\text { Negative Control } \\
\chi \pm S D\end{array}$ & \\
\hline Body Weight (gr) & $13,80 \pm 16,10$ & $13,81 \pm 21,29$ & $4,01 \pm 16,82$ & $16,21 \pm 6,13$ & 0,492 \\
\hline Blood Glucose (mg/dL) & $-162,29 \pm 76,74$ & $-111,00 \pm 44,23$ & $41,28 \pm 53,19$ & $41,285 \pm 53,119$ & $0,000 a^{*}$ \\
\hline $\mathrm{MDA}(\mathrm{nmol} / \mathrm{mL})$ & $-2,86 \pm 0,35$ & $-1,83 \pm 0,07$ & $0,12 \pm 0,20$ & $0,012 \pm 0,020$ & $0,000 b^{*}$ \\
\hline $\mathrm{SOD}(\mathrm{mU} / \mathrm{mL})$ & $8,86 \pm 1,22$ & $13,86 \pm 1,28$ & $-4,89 \pm 6,87$ & $4,08 \pm 4,38$ & $0,000 a^{*}$ \\
\hline $\mathrm{GPx}(\mathrm{mU} / \mathrm{mL})$ & $-22,45 \pm 7,89$ & $-18,08 \pm 7,26$ & $-11,25 \pm 5,96$ & $1,43 \pm 1,45$ & $0,000 a^{* *}$ \\
\hline Catalase $(\mathrm{mU} / \mathrm{mL})$ & $3,09 \pm 0,33$ & $3,32 \pm 0,12$ & $-0,42 \pm 0,29$ & $3,15 \pm 0,34$ & $0,000 a^{*}$ \\
\hline
\end{tabular}

a). Oneway Anova

${ }^{*}$ significance $p<0,05{ }^{* *}$ significance $\left.p<0,001 \quad b\right)$. Kruskal Wallis


Clear kefir showed the highest increase of SOD antioxidants capacity $(13,86+1,28 \mathrm{mU} / \mathrm{mL})$ compared to the insulin group $(8,86+1,22$ $\mathrm{mU} / \mathrm{mL}$ ). Catalase showed the highest increase in Clear kefir group about $3,33+0.13 \mathrm{mU} / \mathrm{mL}$, while the insulin group about 3,09 $\pm 0,33$ $\mathrm{mU} / \mathrm{mL}$. GPx antioxidant improved about $16,94+6,66$ for insulin group, and Clear kefir revealed about $-11,8952+8,1907 \mathrm{mU} / \mathrm{mL}$. This achievement tended to close the normal condition. Statistical analysis $(\Delta)$ showed a significant increased of SOD $(p<0,05)$, Catalase and GPx $(p<0.001)$ values.

Characterization of a serial probiotics showed that an average of microorganisms growth about $1.53 \times 107 \mathrm{cfu}$ at fermentation of 16 hours, while 24 hours of fermentation found in as many as $3.4 \times 106 \mathrm{cfu}$, and fermentation for 48 hours gained as much as $1.6 \times 107 \mathrm{cfu}$. In general, the number of microorganisms in kefir products were ranging from $10^{6}-10^{7} \mathrm{cfu}$. Probiotics will have functional roles if the amount is minimally at $10^{6} \mathrm{cfu}$, threfore the Clear kefir has met the requirements of research. Probiotics used were Lactobacillus Sp, Lactococcus sp and Saccharomyces sp. Findings of this study has proven for least four out of five species of microorganism in the previous theory, such as: Lactobacillus $S p, S p$ Lactococcus and Acetobacter and Saccharomyces Sp. ${ }^{27}$

\section{DISCUSSION}

This study has demonstrated to prove the hypotheses and build a new theory, that oral Clear kefir supplementation of $3,6 \mathrm{cc} / 200 \mathrm{~g} \mathrm{bw} /$ day given for 30 days, significantly affected blood glucose and antioxidants (SOD, GPX, Catalase). Based on the results, it revealed that the mechanism of Clear kefir initially played lowering blood glucose, in fact, it also decreased subsequently on free radicals, lipid peroxidation. Decrease peroxide molecules inhibited proinflammation cytokines production $\left(\mathrm{IL}_{1}, \mathrm{IL}_{6}, \mathrm{TNF}_{\mathrm{a}}\right)$, so that damage to cell structure and function of pancreatic $\beta$ inevitable. $28-30$ Blood glucose, at the normal levels, can prevent the formation of free radicals and reactive oxygen species. Reduction free radicals can lead to ROS production and balance the body's cellular defenses (antioxidants), so the link to oxidative stress exposure can be avoided. Kefir prevents against glucotoxicity and lipotoxicity and reduces the occurrence of hyperglycaemia. These abilities are associated to bioactivity found in kefir.

Studies in vitro support that kefir is lowering blood glucose. ${ }^{31}$ Another mechanism of EPS is to modulate insulin signaling through C-AMP. Increased C-AMP in pancreatic cells contributes to the increased of insulin secretion from pancreatic $\beta$ cells.

Kefir's antioxidants inhibit oxidation, reducing hydroxyl radicals, superoxide and peroxide. The antioxidant activity delivers its hydrogen atoms NADP, which will further reduce the existing free radicals. Lower antioxidant effects through the reduction process malondialdehyde (MDA) peroxidation and suppress pro-inflammatory activity of TNF $\alpha$, resulting an improvement of pancreatic $\beta$ cells through cell regeneration and improvement in organ pancreatic $\beta$ cells.

Kefir showed its ability as hypocholesterolemic agent. The mechanism relies on the presence of salt hydrolase bile enzyme, which binds cholesterol in the digestive tract causing hypocholesterolemic effect. Higher cholesterol impacts lipid peroxidation in the long term effect.

\section{CONCLUSIONS AND RECOMMENDATIONS}

Kefir supplementation had significantly decreased blood glucose, MDA and increased of antioxidants capacity. The number of probiotics declined during storage. It is recommended to conduct multistream elaboration type of bioactive kefir which potentially plays in repairing $\beta$ cells at pancreatic organ for future studies.

\section{ACKNOWLEDGEMENT}

This study was financially supported by Indonesian Danone Institute Foundation. The thanks expressed here are from the authors, and do not necessarily reflect Indonesian Danone Institute Foundation. We express our gratitude to the late Professor Endang Purwaningsih for her supports and ideas on the implementation of this study. 


\section{REFERENCES}

1. WHO. Prevalence of diabetes worldwide http: //www.who.int/ diabetes/facts /world_figures/en/, 2008.

2. American Diabetes Association (ADA). Diagnosis dan Clasification of Diabetes Mellitus. Jurnal Diabetes Care, 2008. (31), 1, January 2008.

3. Hadisaputro S, Setyawan H. Faktor-Faktor yang berpengaruh terhadap kejadian Diabetes mellitus tipe 2, Naskah Lengkap Diabetes Melitus Ditinjau dari Berbagai Aspek Penyakit Dalam. Semarang: Badan Penerbit Universitas Diponegoro. 2007: $p$. 133-154.

4. Betteridge DJ. What is oxidative stress? Metabolism Clinical and Experimental, (49), 2, Supplemen 1, 2000: p. 3-6

5. Ceriello A. Oxidative Stress and Glycemic Regulation. Metabolism (49),2 Supplement 2000 : p. $27-29$.

6. Pfaffy. Diabetic Complications, Hyperglicemia \& Free Radicals. lowa City: Biosciences Departement The University of lowa, 2001.

7. Djokomoeljanto RRJ. Neuropati Diabetik dalam Naskah Lengkap Diabetes Melitus ditinjau dari berbagai Aspek penyakit dalam editor Darmono, dkk. Semarang: Badan Penerbit Universitas Diponegoro, , 2007. Hal. 1-14.

8. Soeyono S. Resistensi insulin, Disfungsi sel $\beta$ dan Peran antioksidan dalam terapi diabetes melitus. Dalam Prosiding Pekan IImiah Nasional Assosiasi Dietisien Indonesia. S.I: AsDI, 2005.

9. Brownlee, M. The Pathobiology of Diabetic Complications. A Unifying Mechanism. Diabetes. 2005; 54(June): 1615- 1624

10. Ziegler D, Christoph GH, Jaffar NZ. Oxidative Stress and Antioxidant Defense in Relation to Severity of Diabetic Polyneuropathy and CardiovasCular Autonomic Neuropathy. Diabetes Care. 2004: 27(9); $2178-2182$.
11. Handelman GJ, Pryor WA. Evaluation of Antioxidant Status in Human. In M Papas, editors. Antioxidant. S.I: Andreas,1998.

12. Inayati lis. Pengaruh ekstrak etanol bahan mahkotadewa (Phaleria macrocarpa (scheff) terhadap kadar MDA tikus diabetes melitus yang diinduksi dengan alloxan. Medika Kartika. 2004: 2(2): 69-80.

13. Hendromartono. Peran radikal bebas terhadap komplikasi vaskuler Diabetes melitus tipe 2, Majalah Penyakit Dalam, 2000: 1(Mei):89-90

14. Blum $S$. The influence of probiotic organisms on the immune response. Nutrition and Immunology, Principle and Practice. New Jersey: Humana Press, 2000.

15. Hanson CK. Medical Nutrition Therapy. Joslin's DiabetesMelitus Fourteent edition. Philadelphia: Lippincott Williams \& Wilkins, 2005.

16. Perkumpulan Endokrinologi Indonesia (PERKENI). Konsensus Pengelolaan Diabetes Melitus di Indonesia. Jakarta: PERKENI, 2007.

17. Hadisaputro S, Riwanto Ign, Subagio HW, Judiono, Laksono B, Watuguly $\mathrm{T}$. Pendekatan Pengobatan Tradisional Untuk Tatalaksana Penyakit Infeksi HIVIAIDS dan Penyakit Degeneratif (Diabetes Mellitus dan Kanker Paru). Laporan Akhir Hibah Pasca Sarjana. Semarang: Universitas Diponegoro, 2008.

18. Brown AC, Ana-Valiere. Probiotics and Medical Nutrition Therapy, Nutr Clin Care. $2004 ; 7(2)$ : 56-68.

19. Sybesma WF, Hugenholtz. Food fermentation by lactic acid bacteria for prevention of cardiovascular: Dalam Functional foods, cardiovascular disease and diabetes. England: Woodhead Publishing Limited, 2004.

20. Khazrai YM, Manfrini $M$ and Pozzilli P. Diet and diabetes: prevention and control. Dalam Functional foods, cardiovasCular disease and diabetes. England: Woodhead, 2004. 
21. Virtanen SM. Nutritional risk factors in the development of type 1 and type 2 diabetes. Dalam Functional foods, cardiovasCular disease and'diabetes. England: Woodhead Publishing Limited, 2004.

22. Hulley SB, Cumming SR, Grady D. Designing a Randomized Blinded Trial. Dalam Designing Clinical Research, 3rd Edition. Philadelphia, USA: Lippincott Williams \& Wilkins.

23. Sigma-Aldrich USA. Product info Streptozotocin from Sigma-Aldrich. Cat. No. S0130. http://www.sigmaaldrich.com/php.June 13, 2009

24. Reeves PG. Components of the AIN-93 Diets as Improvements in the AIN-76A Diet. Journal of Nutrition. 1997; 127(5).

25. Lopitz-Otsoa, Fernando, Rementeria A, Natalia E, Garaizar J. Kefir: A sysmbiotic yeasts-bacteria community with alleged healthy capabilities. Rev Iberoam Micol. 2006;(23),: 67-74

26. Jonas JC, Sharma A, Hansenkamp W. Chronic hyperglycemia triggers loss of pancreatic $\beta$ cell differentiation in an animal model of diabetes. Journal of Biolological Chemistry.1999;(274), p: 14112-141221.

27. Poitout V. Minireview: Secondary $\beta$ cell failure in type 2 diabetes- a convergence of glucotoxity and lipotoxicity. Endocrinology 2002,143; p. 339-342.

28. Kim WH, Lee JW, Suh JH. Exposure to chronic hig glucose induce $\beta$ cell apoptosis through decrease interaction of glucokinase with mitichondria. Diabetes 2005; (54), p: 2602-2611.

29. Maeda H, Xia Zhu, Kazunobu O, Shiho S, Shinichi K. Effects of an exopolysaccharide (kefiran) on lipids, blood pressure, blood glucose, and constipation. BioFactors 2004; 22 (1-4), p. 197-200

30. Ariyuniastuti, Purwaningsih E. Pengaruh pemberian susu fermentasi Lactobacillus casei Galur Shirota terhadap Kadar fraksi lipid serum dan jumlah Coliform serta Lactobacilli. M. Med Indonesiana 2004;39(4),hal. 187 - 194.

31. Almatsier Sunita. Prinsip Dasar IImu Gizi. Jakarta: Gramedia Pustaka Utama, 2003. 